\title{
C. Riskin, R. Zhao and S. Li, eds., China's Retreat from Equality-Income Distribution and Economic Transition
}

M. E. Sharpe, 2001, 222 p.

Sylvie Démurger

URL : http://journals.openedition.org/chinaperspectives/399

DOI : 10.4000/chinaperspectives.399

ISSN : 1996-4617

Éditeur

Centre d'étude français sur la Chine contemporaine

Édition imprimée

Date de publication : 1 août 2003

ISSN : 2070-3449

\section{Référence électronique}

Sylvie Démurger, « C. Riskin, R. Zhao and S. Li, eds., China's Retreat from Equality-Income Distribution and Economic Transition », China Perspectives [En ligne], 48 | july- august 2003, mis en ligne le 24 novembre 2006, consulté le 24 septembre 2020. URL : http://journals.openedition.org/ chinaperspectives/399; DOI : https://doi.org/10.4000/chinaperspectives.399 


\title{
C. Riskin, R. Zhao and S. Li, eds., China's Retreat from Equality- Income Distribution and Economic Transition
}

\author{
M. E. Sharpe, 2001, 222 p.
}

Sylvie Démurger

\section{NOTE DE L'ÉDITEUR}

Translated from the French original by Nick Oates

1 WITH the help of two national surveys, one among rural and the other among urban households, this collective work offers a detailed analysis of how income distribution evolved in China between 1988 and 1995. The study put forward here can be read as a complement to two works published by Griffin and Zhao (1993) and Khan and Riskin (2001), the first of which presents the results of the 1988 survey and the second the results of the 1995 survey. The aim of this third volume is to provide elements that explain the evolution observed in income distribution between these two years, and its preferred method of explanation is by reference to market reforms.

2 The work combines qualitative analyses with a very complete set of quantitative analyses based on the data collected on household income in 1988 and 1995. The various chapters offer an exhaustive view of the mechanisms which underlie the evolution of the income distribution profile during the first half of the 1990s, a period marked by an unstable macroeconomic situation that nevertheless permitted real GDP to virtually double during the seven years that separate the two surveys.

The first part of the work underlines the rapid and significant evolution of the inequalities in income in China between 1988 and 1995 (+20\% for the Gini calculated on the equivalent income per adult), which confirms a pronounced increase in inequalities 
in both rural and urban incomes (of $30 \%$ and $21 \%$ respectively). On the other hand, if the general inequality in China remains dominated by the strong deviation in ruralurban income, the contribution made by that deviation showed a tendency to decrease between 1988 and 1995 as a result of the sharp rise in inequality within the urban and, in particular, rural zones.

Whatever the indicators retained to measure income and its distribution, the widening of the inequalities in China during the reform period is undeniable. The question of the evolution of income distribution today constitutes an important challenge because of its potentially significant negative consequences in terms of social welfare and the sustainability of the growth process. However, one of the contributions made by this work (underpinned in particular in Chapter 2) is to qualify the extent of this increase, which, at first sight, may appear spectacular in relation to the relatively egalitarian distribution of income prevailing at the end of the Maoist period. Indeed, Zhao Renwei underlines the importance, before the reforms were launched, that benefits in kind played in income, in particular for the urban population, which rendered the distribution of monetary incomes artificially equitable. Moreover, the freezing of wages - which made up the essential part of incomes - that was imposed for twenty-odd years introduced intergenerational distortions within the urban zones. Thus, without denying the rapid widening of the inequalities in China which accompanied the implementation of the reforms, the retrospective analyses put forward in this work serve to temper the pessimism of the conclusions as far as the explosion of these inequalities is concerned. From this perspective, the different chapters suggest a complementary interpretation, in so far as the adoption of mechanisms of the market economy has led to necessary adjustments, which contrast with a situation where the absence of markets, particularly a labour market, and the dominance of the plan on economic activities determined the income distribution profile in an arbitrary manner. Thus, it seems possible to attribute one part at least of the observed rise to a phenomenon of "catch-up" resulting from the progressive transformation of the Chinese economy into an economy guided by market forces.

5 The mechanisms which have led to this increase in inequality in China are complex. It is first necessary to distinguish rural China from urban China, and this is the aim of parts 2 and 3 of the work. In this distinction, the origins of the incomes are formed by very different sources, and the economic reforms have had a differentiated impact on the evolution of income distribution (within the two categories as well as between them). To this rural/urban distinction is added a regional one between coastal China and the interior. Finally, within these categories, it is necessary also to distinguish what, in the evolution of the income distribution, originates on the one hand from sources of income (the increasing importance of wages in rural incomes for example) and on the other from returns based on the characteristics of the individual (the role of education particularly in the explanation of regional differences in urban incomes). This distinction is of interest in terms of economic policy in so far as the problem of access to the factors that enable income to be increased is often posed in a sharp manner for the most underprivileged populations. This is particularly the case in education, to which, the authors demonstrate, ethnic minorities (Chapter 3) and poor migrants (Chapter 13) have little access.

6 The work also dedicates a chapter to the study of rural poverty. Contrary to the official figures, Carl Riskin and Li Shi reveal that the poverty rate in rural China remained 
constant between 1988 and 1995, which means that the absolute number of those living in poverty increased. They similarly show that half of the poor live outside zones officially designated as such and that the representation of national minorities among the poor living outside these zones soared significantly between 1988 and 1995. At a time when the new government is clearly flaunting the reduction of poverty and the improvement of living conditions in rural communities as priority targets, the questions discussed with great rigour in the third part of this work concerning poverty, nutrition, migration and the distribution of land in rural China seem especially topical.

7 If the analysis put forward opens up a number of interesting paths, it is nevertheless regrettable that the authors fail to go beyond the purely descriptive framework that offers traditional methods for the decomposition of inequality. Recourse to more recent complementary techniques, such as the methods of micro-simulation decompositions that explicitly integrate a modelisation of the labour market, would have allowed a clearer light to have been shone on the profound changes that have taken place in the labour market and their impact on income distribution. Within this framework, the evolution of employment and unemployment and the expansion of career choices (through the development of township and village enterprises and of the private sector in particular) are certainly key factors in the evolution of income distribution.

These few remarks take nothing away from the quality of this work. The analysis, complete and documented, of the evolution of inequalities at the start of the 1990s presents an obvious interest from both a scientific and an economic policy viewpoint. Moreover, this is certainly a first stage in the study of the evolution of income distribution in the course of the process of reform and development. The current work being conducted on a third survey (1999) should allow a more complete vision to be gained of the evolution of the inequalities over the whole course of that decade. 